\title{
Teaching Practices and School Climate: The Portuguese Students' Views
}

\section{Paula Borges}

Instituto Superior de Educação e Trabalho (ISET) - Porto (Portugal)

doi: 10.7358/ecps-2015-011-borg

paulabor@gmail.com

\section{PRATICHE DI INSEGNAMENTO E CLIMA SCOLASTICO: LE OPINIONI DEGLI STUDENTI PORTOGHESI}

\begin{abstract}
Considering that organizational climate corresponds to what organizational actors mostly represent and with regard to their organization and taking into account that the most intense student experiences occur within the classroom, we wanted to know whether student views on teachers' leadership and practices are related to what they perceive as school climate. The students came from schools all over Portugal, including Madeira. Regarding teaching practices, we focused our attention on the following dimensions: teaching; support to learning control; lack of support for individual work; use of methods that engage students differently in their work. As regards school climate, we considered the following dimensions: colleagues, teachers and class director relations; equity; safety; working conditions. Teachers' leadership and educational practices have highly significant statistical relations with the different dimensions of school climate. Students stress that teachers who are democratic leaders use educational practices viewed as democratic classroom strategies. Moreover, the quality of the relationships they develop with their colleagues, teachers and class directors are pertinent to the consideration of a positive school climate. Equity, safety and working conditions also significantly contribute to the consideration of a positive school climate. The results show that teachers and school leaders need to continue to reflect upon classroom working practices.
\end{abstract}

Keywords: Leadership, Teaching practices, School climate, Students, Teachers. 
If we understand, like Teixeira (2013), that climate "corresponds to what organizational actors mostly represent and feel of their organization" and that "classrooms, nested as they are within schools, have climates that directly or indirectly are influenced by the wider school climate» (Anderson, 1982), then educational practices may inscribe themselves as a shared image framework that allows you to interpret and see the world in a particular manner, and, as it is the case, will enable you to envisage school as a particular climate setting.

\section{SCHOol Climate}

When listing the reasons underpinning climate research and school climate, in particular, Anderson (1982) states that one of the unifying threads in school climate research is the one which considers that «climate is influenced by, not a proxy for, particular dimensions of the school such as body characteristics $[\ldots]$ or classroom processes».

Cohen, Mccabe, Michelli and Pickeral (2009) in turn state that «school climate is based on patterns of people's experiences of school life and reflects norms, goals, values, interpersonal relationships, teaching and learning practices, and organizational structures", and that from the observation of the research conducted over the last three decades, four major areas and subdimensions emerge. Of these four areas and sub-dimensions, we emphasize the second - teaching and learning - and its four sub-dimensions - quality of instruction; social, emotional and ethical learning; professional development; and leadership.

When presenting the third edition of the Classroom Environment Scale (CES) Manual, Trickett and Moos (2002) underline the fact that the CES is composed of nine subscales that assess «three underlying sets of dimensions: relationship dimensions, personal growth or goal orientation dimensions and system maintenance and change dimensions» and that it intends to tap "dimensions that reflect the teachers' dual responsibility to maintain conditions in which students can learn and to provide effective support for them».

Taking into account the reasons given above, we are led to believe that school climate and the social representations that students have of teachers, and especially of their educational practices, can somehow be related.

This consideration gains greater relevance when we subscribe to Teixeira's (2008) concept of climate and intend to use her school climate dimensions in our own research. Teixeira states that the school image students have is likely to be measured by "the relations that are established and the working conditions». Hence, in order to conduct her research, in 2004 and 2007 she 
established the following dimensions as the students' view of school climate: relationships among peers, with teachers, and with the class directors, and attitudes towards school work. The results obtained, both in 2004 and 2007, point to a positive view of the relations that students develop with teachers, with class directors, with colleagues and even towards school work. Bearing this in mind and taking into account that a new survey was being conducted in 2013 by Teixeira, we decided to test her results against the image students have of teachers' educational practices and if they have significant relations with the way they feel about the school climate, according to the relationship, equity, safety and working conditions dimensions that Teixeira (2013) defined.

\section{THE TEACHER - LEADERSHIP AND EDUCATIONAL PRACTICES}

The teaching profession is a relationship profession and is developed by individuals who are, above all, relationship beings. Teaching and being a teacher means being in constant relation with others, being in constant interaction with students, peers, parents and staff. Being a teacher means constantly experiencing daily interaction and relationship exchanges. It means that there is a constant game going on among the different actors. It is a «common ground of 'freedoms', of 'plays' of 'unpredictability'" (Demailly, 1982).

This unpredictability arises from the fact that the teacher seeks to make things happen, to make the results and procedures be the intended ones and that they might collide with the will of those over which they intend to exercise a certain leadership.

Teachers exert leadership legitimized by the position they hold in the organization. And by organization we are referring not only to the so-called school organization, but also to the classroom organization. It is the teacher who controls the rewards, punishments, information, resources, rules, tasks and decision-making. Finally, it is the teacher that draws up and puts into practice a set of educational practices. Educational practices, which as Altet (2000) said, have a wide field of action that involves the ability to «transform teachers' information into knowledge through communication in the classroom; [make] the interactive global management of information flows and events in class, [conduct] predetermined activities and methodology planning; [manage] class progression and interactive decision-making». In fact, the teacher is the expert who holds the power of scientific, pedagogical and didactic knowledge: it is the teacher who knows and manages the syllabus, defines tasks, puts them into practice, enforces and assesses the processes and results. Thus, s/he plays the role of a leader - a role that derives from the 
knowledge s/he holds, but which can also derive from the emotional relationship s/he has with her/his students over time.

The exercise of leadership is thus closely linked to the type of leadership that the teacher plays in or outside the classroom with the students. The teacher will be a leader irrespective of the way s/he influences his/her students so that they "perform assigned tasks willingly and in an efficient and effective manner» (Blacksacademy, 2005). We are then led to believe that teachers' leadership is linked to the educational practices they use with their students.

Hence, to talk about leadership and educational practices means talking about different leadership approaches and different practices associated with it. Of all the possible styles or approaches of leadership, we will adopt Kurt Lewin and Ronald Lippit's (1938) typology because it seems to us to be the closest to what happens within the classroom in teacher and student relations. We are talking about two styles: autocratic and democratic leadership.

Let us see how each of these styles can match different educational practices.

The autocratic teacher leader uses unilateral communication with the students to make them understand the importance of fulfilling objectives, the tasks to be performed, and the standards to be met in the classroom. The autocratic leader focuses primarily on his/her ability to transmit knowledge, and uses a large amount of time in class to do it. The teacher focuses on work performance, on the production of exercises that will consolidate knowledge and will enable students to learn the subjects. Time to participate, to create, to develop autonomy, to do research will be sparse and will always be closely supervised by the teacher. In terms of the teaching materials, s/he will almost exclusively adopt textbooks and documents produced by him/herself or by peers.

Teachers who adopt a democratic style use two-way communication. They encourage students to participate in the decisions to be taken and establish agreements among themselves in order to be most effective. Hence, they build a participatory, relaxed, personal and supportive climate (Schmuck $\&$ Schmuck, 2007). They seek to create a close relationship with the students as this is essential for adherence to the teaching of a subject. They will be open to active participation, to the challenge stemming from the issues raised by the students, whether or not they are related to the subject they are teaching. They use group work dynamics and inspire in their students the desire for discovery, to foster research, and they develop the ability to learn and enjoy learning. They seek to use all the resources that are at their disposal, be they manuals, worksheets, new technologies or media information in order to motivate students to learn. They seek and develop research strategies with their students to enable them to be open to new paths and new questions, in order to acquire knowledge and skills that can even go beyond the centrally defined syllabus. 


\section{Methods}

In order to know students' opinions regarding the representations they have of educational teaching practices and their relationship with school climate, we devised a questionnaire survey in partnership with Alves-Pinto (2013) and Teixeira (2013), and it was implemented with students attending Portuguese schools.

Descriptive and inferential analysis of the results obtained were made through the use of $\chi^{2}$ Pearson test and we took into consideration the less than 0.001 variance. The questionnaire concerning the educational teaching practices replicates some issues of an instrument designed nine years ago.

Analysis of the two types of leadership will be presented through the operationalization of teachers' educational practices in the following dimensions: democratic leader; teaching, support for learning control; discovery method; autocratic leader; lack of support for individual work; the expository method. We will also present the variations of the students' opinions according to the climate dimensions, sub-dimensions and indicators Teixeira used - in the questionnaire that we share - in her 2013 research, and namely; colleagues, teachers and class director relations; equity; safety; and working conditions.

\subsection{Research sample}

The sample consisted of 3,860 students from 5th to 12th-graders from schools in the North, Central, Greater Lisbon, Alentejo, Algarve and Madeira areas. The sample constitution, considering the aggregate results, was as follows:

- By age: 10 to 12 years $-20.57 \%$; 13 to 15 years $-36.84 \%$; 16 to 23 years $40.76 \%$.

- By gender: boys $-52.28 \%$; girls $-47.72 \%$.

- By study cycle: 2 nd cycle $-13.62 \%$; 3rd cycle $-40.51 \%$; secondary $45.88 \%$.

- By level of family schooling: 4th to 9 th grade $-38.09 \%$; 9 th to 12 th grade $63.6 \%$; over 12 th grade $-31.52 \%$.

A subsample of high school students included $50.14 \%$ of students in scientific-humanistic courses and $49.86 \%$ of professional/vocational courses. 


\section{RESULTS AND ANALYSIS}

\subsection{Leadership and teachers' educational practices}

Here we present the results obtained taking into account the types of leadership operationalized through teaching practices in the following dimensions: democratic leader; teaching; support for learning control; discovery method; autocratic leader; lack of support for individual work; the expository method.

We shall not give the intermediate responses for any of the dimensions presented. Both the lower and upper responses have been added up and a simplified description has been applied. Thus, «all», «the majority», «most frequently» and "frequently» are referred to as «majority/frequently», while "few» or «none» and «infrequently» or "rarely» are designated as "few/rarely». The intermediate position is determined by removing the sum of the results of the extremes out of 100 . With appropriate adjustments whenever necessary, those were the terms used for the graphic display of the response frequency.

\subsubsection{Democratic leader - Teaching, support on learning control, discovery method}

In order to know the students' opinions on their teachers' type of democratic leadership, we built indicators on dimensions that were previously considered regarding their educational practices - teaching, support for learning control, and discovery method, as can be seen in the Table 1 .

Table 1. - Democratic leader dimensions.

\begin{tabular}{ll}
\hline \multicolumn{1}{c}{ Dimensions } & \multicolumn{1}{c}{ InDiCATORS/QUESTIONS } \\
\hline Teaching & $\begin{array}{l}\text { Clearly explain matters. } \\
\text { Arouse curiosity by the various materials they teach. }\end{array}$ \\
\hline \multirow{3}{*}{ Support on learning control } & $\begin{array}{l}\text { Do lots of exercises on each of the issues to see if you learned. } \\
\text { They support and give suggestions when a student } \\
\text { has difulties in solving assignments, papers }\end{array}$ \\
\hline \multirow{2}{*}{ or understanding of matters. }
\end{tabular}


For each of the items, we asked (on a five-point scale ranging from «none» to «all») how many of the teachers used them or how often these actions occurred.

\subsubsection{Data analysis}

We shall introduce the data collected on the three defined dimensions for democratic leader. In each case, we will analyze the existence of possible relations with the respondent's profile in terms of gender, age and level of family schooling.

The response distribution with regard to the two indicators for each dimension is contained in Figure 1.

Figure 1 gives evidence that a majority of respondents said that teachers often use support for learning control and care about teaching practices. A majority said that rarely or few teachers use the discovery method in their classrooms.

It may thus be concluded that students' opinions are mostly favorable to teachers using a kind of democratic leadership in the classroom.

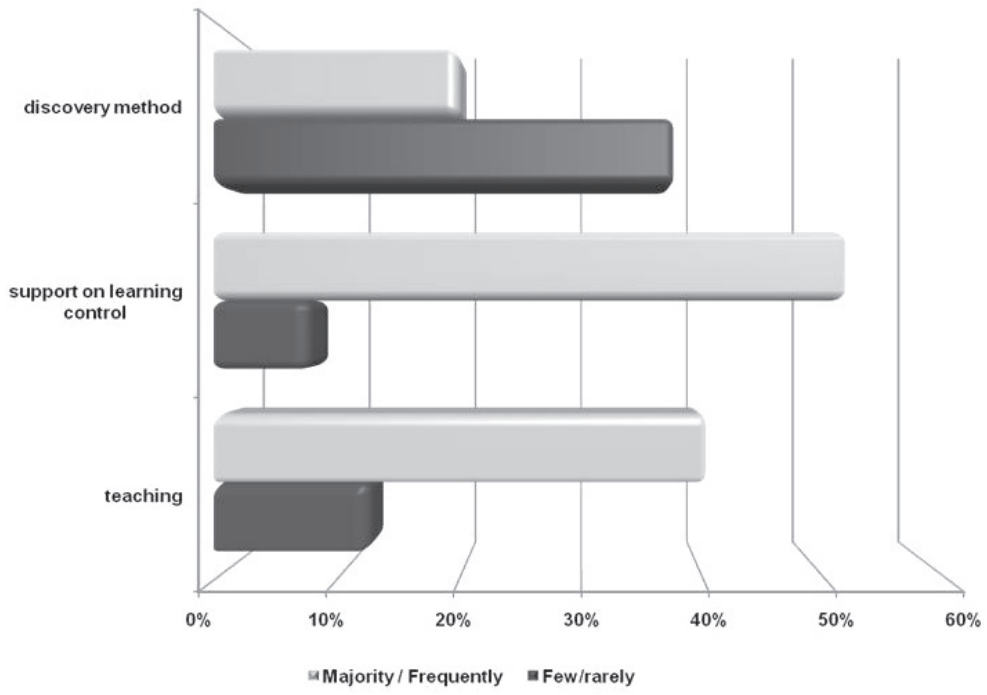

Figure 1. - Frequency of responses to democratic leader educational practice questions. 
The image they have of the teacher as leader is that of someone who makes choices of practices that take into account how students adhere to the subject, to the contents and the learning process. They also take into account the imparting of knowledge and the control on the acquisitions they promote and raise the will of students' to discover; they provide research and develop the ability to learn and enjoy learning. However, they also indicate that there is one aspect that is somewhat less often used by teachers: the incentive for students to participate in the decisions to be taken and to establish agreements among themselves.

For each considered aspect, we sought the existence of correlations according to the respondents' profile: age, gender, study cycle, type of education and level of family schooling.

The results show that the boys, the youngest students, those attending the 5th and 6th grades, and students attending professional/vocational education are the ones who very significantly say that teachers use a democratic type of leadership when they express their opinions on educational practices related to teaching and the use of the discovery method.

Regarding support for learning control, only the youngest and those attending the 5th and 6th grades say it occurs. We found an homogeneity of opinion with regard to other profile variables.

We highlight the fact that there are only significant variations when we consider the level of family schooling and the dimensions of teaching and the use of the discovery method. Thus, when it comes to the teaching dimension, students whose parents have an intermediate level of education are the ones who have a higher opinion of the use of the discovery method. Students whose parents have a lower level of education are the ones who have a higher opinion.

\subsubsection{Autocratic leader - Lack of support for individual work and the expository method}

As we said above, the autocratic teacher leader focuses mainly on the ability to impart knowledge, uses a large amount of time in class to do it, focuses on work performance, on the production of exercises that will consolidate knowledge and will enable students to learn the subjects: the expository method is the educational practice used.

Participatory, creative and autonomous research moments are sparse and if they happen, they are always closely supervised by the teacher who almost exclusively adopts textbooks and documents produced by him/herself or by peers - which in terms of educational practices can be translated in to the lack of support for individual work. 
Table 2. - Autocratic leader dimensions.

\begin{tabular}{ll}
\hline \multicolumn{1}{c}{ Dimensions } & \multicolumn{1}{c}{ InDiCATORS/QUESTIONS } \\
\hline Expository method & $\begin{array}{l}\text { Books are the only material used to present the new is- } \\
\text { sues even when using the computer. } \\
\text { To participate, students must take the floor and speak } \\
\text { only on issues that were explained. }\end{array}$ \\
\hline Lack of support for individual work & $\begin{array}{l}\text { Encourage students to give their views and to discuss } \\
\text { with colleagues the new points of different issues. } \\
\text { Use TV programs, newspapers, news or computers and } \\
\text { the Internet to present new issues. }\end{array}$ \\
\hline
\end{tabular}

Like we did with the democratic leadership dimension, we also built indicators on dimensions that were previously considered with regard to their educational practices: lack of support for individual work and the expository method, as can be seen in Table 2 .

\subsubsection{Data analysis}

We shall introduce the data collected on the two defined dimensions for autocratic leader. Again, in each case, we will analyze the existence of possible relations with the respondents' profile in terms of gender, age and level of family schooling. The response distribution with regard to the two indicators for each dimension is contained in Figure 2.

As Figure 2 shows, a slim majority of students believe that teachers use an autocratic leadership; only $10.84 \%$ of the students admit that all or most of the teachers lack support for individual work. With regard to the use of an expository method, $27.34 \%$ of the students said that most do.

Comparing this with the previous Figure, it seems reasonable to conclude that students understand that the educational practices of teachers are focused on the pursuit of a democratic leadership.

Again, as we did for the democratic leadership dimension, we sought the views of pupils on each aspect considered according to the students' profile: age, gender, study cycle, type of education and level of family schooling.

Boys and those attending secondary education and scientific-humanistic courses are the ones that claim the most that few or rarely do teachers use educational practices that prefigure an autocratic leadership.

This trend can still be observed with those that are between 13 and 15 years of age with respect to lack of support for individual work. As regards an expository method, the oldest students are the ones who say they have experienced it. 


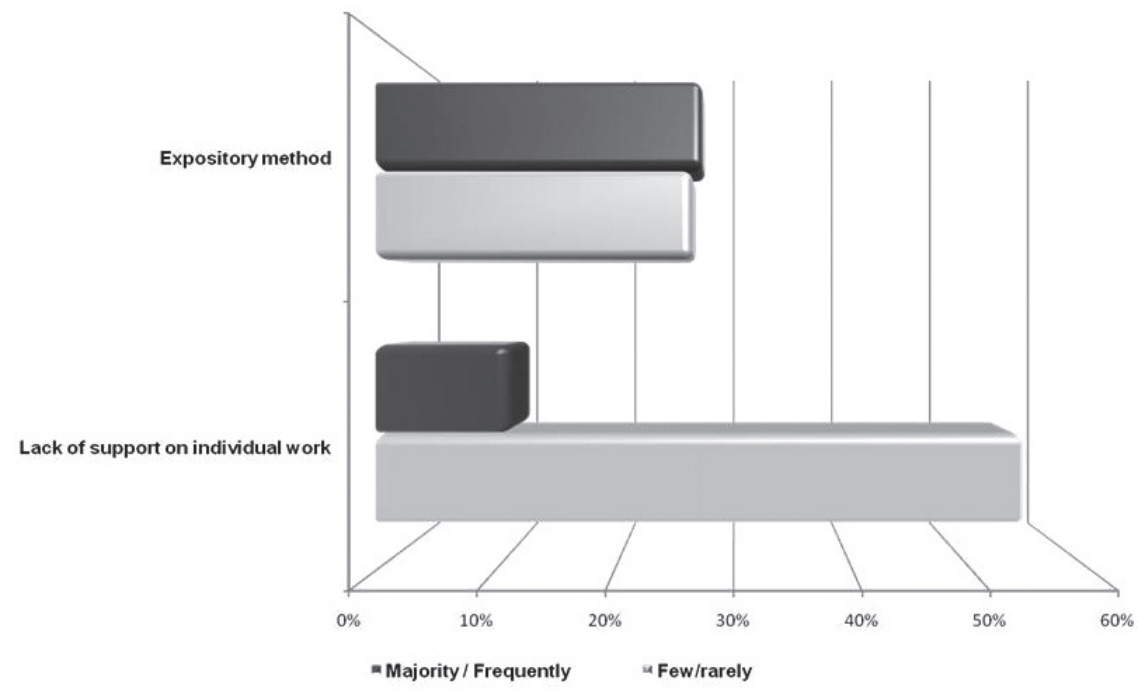

Figure 2. - Frequency of responses to autocratic leader educational practice dimensions.

Finally, the students whose parents have a higher level of family schooling are the ones who claim that most teachers do not use teaching practices conducive to the exercise of an autocratic leadership.

If we consider what Kurt Lewin and Ronald Lippitt claim to be the attitudes and reactions of students (1938) in classrooms whose teachers developed educational practices conducive to the exercise of a democratic or autocratic leadership, we can say that it is expected that in the classrooms of democratic leader teachers, students develop more cooperative behaviors, there is greater communication, greater group structure stability, a higher incidence of constructive suggestions, a greater sense of belonging to the group, a building of a "we» feeling, and more instances of praise and expressions of friendship.

If these behaviors occur, then we will probably have a positive perception of the classroom climate and, subsequently, a positive perception of school climate. Let us now see how these students perceive school climate and if there are visible relations with teachers' leadership and educational practices.

\subsection{Leadership, educational practices and school climate}

Bearing in mind that classroom climate can be seen as «a function of all participants' perceptions of classroom interactions» (Anderson, 1982) and that it may be a school climate component, we tried to understand how students 
who are subject to educational practices that oscillate between an autocratic or a democratic style of leadership feel about it.

The climate indicators we used were defined by Teixeira (2013) in the questionnaire we shared: colleagues, teachers and class director relationships, equity, safety and working conditions (Table 3).

The indicators of each dimension and sub-dimension were constructed by inverting the values of the indicators marked with (-).

Table 3. - Dimensions and indicators of school climate.

\begin{tabular}{|c|c|c|}
\hline DimEnSIONS & Sub-DIMENSIONS & INDICATORS/QUESTIONS \\
\hline \multirow{7}{*}{ 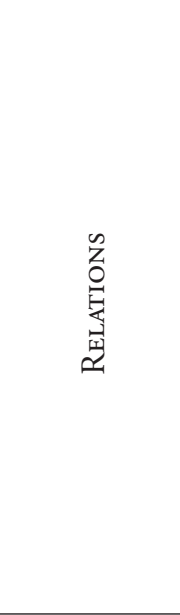 } & \multirow{3}{*}{$\begin{array}{l}\text { Among } \\
\text { colleagues }\end{array}$} & $\begin{array}{l}\text { When I'm worried, I have colleagues with whom } \\
\text { I can talk about what worries me. }\end{array}$ \\
\hline & & $\begin{array}{l}\text { When I have trouble doing something, I have } \\
\text { colleagues who try to help me. }\end{array}$ \\
\hline & & There is a lot of competition among students (-). \\
\hline & $\begin{array}{l}\text { With } \\
\text { teachers }\end{array}$ & $\begin{array}{l}\text { I do not feel comfortable with many teachers (-). } \\
\text { Teachers respect us as people. } \\
\text { Teachers do what they can to motivate us to study. }\end{array}$ \\
\hline & \multirow{3}{*}{$\begin{array}{l}\text { With } \\
\text { the class director }\end{array}$} & $\begin{array}{l}\text { The class director is interested in whether we have } \\
\text { trouble. }\end{array}$ \\
\hline & & $\begin{array}{l}\text { The class director is always available to listen to us } \\
\text { and help solve problems. }\end{array}$ \\
\hline & & $\begin{array}{l}\text { The class director uses only scolding and threatens us } \\
\text { with punishment (-). }\end{array}$ \\
\hline \multirow{3}{*}{\multicolumn{2}{|c|}{ EQUITY }} & Grades are generally fair. \\
\hline & & Teachers explain what the evaluation criteria are. \\
\hline & & Teachers show preference for some students (-). \\
\hline \multirow{3}{*}{\multicolumn{2}{|c|}{ SAFETY }} & There is a lack of safety in access to school (-). \\
\hline & & $\begin{array}{l}\text { At breaks there are often situations where } \\
\text { I feel unsafe (-). }\end{array}$ \\
\hline & & $\begin{array}{l}\text { When there is disturbance, there is always an adult } \\
\text { that intervenes to solve problems. }\end{array}$ \\
\hline \multirow{3}{*}{\multicolumn{2}{|c|}{ WORKING CONDITIONS }} & There are few nice places to hang out (-). \\
\hline & & School is well equipped. \\
\hline & & $\begin{array}{l}\text { In the classroom there is sometimes so much noise } \\
\text { that it ends up distracting us. }\end{array}$ \\
\hline
\end{tabular}




\subsubsection{Democratic leader educational practices and school climate}

Let us look at the answers that students gave about how the educational practices of a teacher with a democratic leadership style relate to what they feel about school climate. To this end, we recall that the indicators that were used for educational practices were teaching, support for learning control, and the discovery method.

As shown in the following table, we note highly significant variations with all indicators. In view of the responses, you can tell that the students who find all of the climate indicators very satisfying are the ones who further claim that in class they experience educational practices that arise from a democratic style of leadership. This positive opinion from students is more significant when we take into account the indicator support for learning control, followed by teaching. Practices related to the discovery method in which teachers encourage students to participate in the decisions to be taken and establish agreements among themselves, as well as use more diverse materials - although perceived positively, registers a less expressive opinion than the previous ones (Table 4).

As regards equity, safety and working conditions, the students who stress democratic educational practice indicators view school climate in a very positive way. Yet, we highlight the fact that with regard to support for learning control, the students' view is highly significant for all climate indicators.

These answers lead us to conclude that both the relations with the different school actors and dimensions such as equity, safety and especially working conditions vary with classroom climate and if it is viewed as positive, then it is possible that it might contribute to a feeling of a positive school climate.

Table 4. - Correlations between democratic leader educational practices and school climate dimensions.

\begin{tabular}{lccc}
\hline \multicolumn{1}{c}{ Dimensions } & TEACHING & $\begin{array}{c}\text { SUPPORT } \\
\text { ON LEARNING } \\
\text { CONTROL }\end{array}$ & $\begin{array}{c}\text { DisCOVERY } \\
\text { METHOD }\end{array}$ \\
\hline Colleagues' relationship & $p<.0000$ & $p<.0000$ & $p=.0126$ \\
Teachers' relationship & $p<.0000$ & $p<.0000$ & $p<.0000$ \\
Class director's relationship & $p<.0000$ & $p<.0000$ & $p<.0000$ \\
Equity & $p<.0000$ & $p<.0000$ & $p<.0000$ \\
Safety & $p<.0000$ & $p<.0000$ & $p<.0000$ \\
Working conditions & $p<.0000$ & $p<.0000$ & $p<.0000$ \\
\hline
\end{tabular}




\subsubsection{Autocratic leader educational practices and school climate}

Regarding the responses that students gave about on how the educational practices of an autocratic leadership style teacher relate to what they feel as school climate, we used the following indicators: expository method and lack of support in individual work - educational practices; colleagues, teachers and class director relationships, equity, safety and working conditions school climate.

Table 5 allows us to conclude that although there are highly significant variations regarding the lack of support in individual work, the same does not happen with the use of the expository method in which there is the greater uniformity of responses.

The variations recorded in relation to the educational practice indicator lack of support in individual work point to the fact that the more positive the student's opinion is with regard to climate indicators, the lower the consideration that this practice is utilized. However, with respect to the use of an expository method, students expressing a highly positive view of the relationship they establish with teachers, of equity and working conditions, are the ones who claim that this method is implemented, although they say this in a not very expressive way.

With regard to safety, those who have a less favorable view are the ones who mostly claim that the expository method is used.

Table 5. - Correlations between autocratic leader, educational practices and school climate dimensions.

\begin{tabular}{lcc}
\hline \multicolumn{1}{c}{ Dimensions } & $\begin{array}{c}\text { LACK OF SUPPORT } \\
\text { IN INDIVIDUAL WORK }\end{array}$ & $\begin{array}{c}\text { EXPOSITORY } \\
\text { METHOD }\end{array}$ \\
\hline Colleagues' relationship & $p<.0000$ & $p=.15$ \\
Teachers'relationship & $p<.0000$ & $p<.0000$ \\
Class director's relationship & $p<.0000$ & $p=.21$ \\
Equity & $p<.0000$ & $p=.0068$ \\
Safety & $p<.0000$ & $p=.0002$ \\
Working conditions & $p=.0001$ & $p=.0064$ \\
\hline
\end{tabular}




\section{CONCLUSIONS}

The responses we obtained from the students suggest the existence of a positive school climate and of a close relationship between this opinion and a relationship between school climate and educational practices. The responses also indicate that the quality of the relationship that students have with colleagues is important when it comes to the contribution of educational practices for positive school-climate building.

But it is, above all, the relationships established with the teachers and class directors - those who value the work they do, who help them in their difficulties, that arouse their curiosity for the subjects they teach with rigor and clarity, that require a job of excellence, that motivate - using proper educational practices of a democratic leadership that provide a positive climate perception, not only of the classroom, but also of the school.

It seems worth recalling that, when speaking about the quality of education and its relation to school climate and performance, Janosz, Georges and Parent (1998) said that schools in which teachers dominate cooperation pedagogies, take care to stimulate feelings of control and competence in students and to seek to develop metacognitive skills are the ones where you can see how the quality of educational practices have a «strong influence in the educational climate».

Janosz, Georges and Parent (1998) are still the ones who remind us, however, that the relations between practices and climate are bidirectional since climate either «facilitates or not the implementation, modification or innovation of practices». This bi-directionality of the relationship between practices and climate immediately directs our focus on the leadership problem.

The opinion of the students that constitute our sample is that there is a strong relation between a positive school climate and practices that lie at the level of democratic leadership. Once the teacher is clearly perceived as a leader, at least, in the classroom, it seems necessary that s/he is able to develop a range of strategies and practices that foster a positive classroom climate. To be able to do so, school leaders must promote conducive spaces for collaborative work.

We agree with Cohen, Mccabe, Michelli and Pickeral (2009) when they state that "preparing school leaders who understand the critical role of a school climate that promotes collaboration and learning communities and teachers who understand the importance of such a climate» is critical. And it is crucial because only by creating organizational conditions that enable teachers to develop educational practices conducive to a democratic leadership style will it be possible to build a "sustainable, positive school climate [that] fosters youth development and learning necessary for a productive, contributive and satisfying life in a democratic society» (Cohen \& Geier, 2010). 


\section{REFERENCES}

Altet, M. (2000). Análise das práticas dos professores e das situaçôes pedagógicas. Porto: Porto Editora.

Alves-Pinto, M. C. (2013). Os jovens e a cidadania em 2013; o olhar de alunos do ensino secundário. In F. H. Veiga (Coord.), Envolvimento dos alunos na escola: perspetivas internacionais da psicologia e educação. Students' engagement in school: international perspectives of psychology and education. Lisboa: Instituto de Educação da Universidade de Lisboa (2014).

Anderson, C. S. (1982). The search for school climate: A review of the research. Review of Educational Research, 52 (3), 368-420.

Blacksacademy (2005). Leadership and management styles. http://www.blacksacademy. com.

Cohen, J., \& Geier, V. K. (2010). School climate research summary. http:// www. schoolclimate.org/climate/research.php.

Cohen, J., Mccabe, E., Michelli, N. M., \& Pickeral, T. L. (2009). School climate: Research, policy, practice and teacher education. Teachers College Record, 111(1), 180-213. Retrieved from: http//www.tcrecord.org. ID number: 15220.

Janosz, M., Georges, P., \& Parent, S. (1998). L'environment socioéducatif à l'école secondaire: un modèle théorique pour guider l'evaluation du milieu. Revue Canadienne de Psycho-Education, 27(2), 285-306.

Lewin, K., \& Lippitt, R. (1938). An experimental approach to the study of autocracy and democracy: A preliminary note. Sociometry, 1(3/4), 292-300. Retrieved from: http://links.jstor.org/.

Schmuck, R. A., \& Schmuck, P. A. (2007). Climate teaching strategies - Group processes in the classroom - Classroom as group, a social-psychological view, classroom climate, teaching strategies. http://education.stateuniversity.com/pages/2022/ Group-Processes-in-Classroom.html.

Teixeira, M. (2008). Clima da escola na perspetiva dos alunos. In M. C. Alves-Pinto (Coord.), Alunos na escola - Imagens e interacçôes (pp. 79-116). Porto: ISET.

Teixeira, M. (2013). Olhares dos alunos sobre a escola: clima e sentido de pertença. In F. H. Veiga (Coord.), Envolvimento dos alunos na escola: perspetivas internacionais da psicologia e educação. Students' engagement in school: international perspectives of psychology and education. Lisboa: Instituto de Educaçáo da Universidade de Lisboa (2014).

Trickett, E., \& Moos, R. (2002). Classroom Environment Scale (CES) Manual. Mind Garden, Inc. 


\section{RiassunTO}

Partendo dalla considerazione che il clima di una organizzazione corrisponde a ciò che $i$ suoi membri si rappresentano e tenendo conto che le esperienze più intense degli studenti avvengono all'interno della classe, abbiamo voluto se l'opinione degli studenti studenti (provenienti dal Portogallo, incluso Madeira) sulla leadership e le pratiche degli insegnanti è legato al clima scolastico. Per quanto riguarda le attività didattiche degli insegnanti, abbiamo concentrato l'attenzione sulle seguenti dimensioni: il supporto nell'apprendimento, la mancanza di sostegno al lavoro individuale, l'uso di metodi che coinvolgono in modo diverso gli studenti nel lavoro. Quanto al clima scolastico, abbiamo preso in considerazione le seguenti dimensioni: $i$ colleghi, le relazioni tra i docenti e il coordinatore di classe, l'equità, la sicurezza e le condizioni di lavoro. Il rapporto tra le attività dei docenti che riguardano leadership e formazione e le diverse dimensioni del clima scolastico mostrano una alta significatività statistica. Gli studenti sottolineano che gli insegnanti che sono leader democratici usano pratiche educative riconoscibili come strategie democratiche di gestione della classe. Inoltre, la qualità delle relazioni che essi sviluppano con i compagni, con gli insegnanti e i coordinatori di classe, sono in stretto rapporto al clima scolastico, che è collegato, in modo molto significativo, anche all'equità, alla sicurezza e alle condizioni di lavoro. Questi risultati mostrano l'utilità del fatto che insegnanti e dirigenti scolastici continuino a riflettere sulle pratiche di lavoro attuate in classe.

Parole chiave: Clima scolastico, Insegnanti, Leadership, Practiche educative, Studenti. 